\title{
Energy Requirements for Loss of Viral Infectivity
}

\author{
Caroline E. R. Rowell ${ }^{1,2} \cdot$ Hana M. Dobrovolny ${ }^{2}$ (])
}

Received: 21 May 2020 / Accepted: 31 July 2020 / Published online: 5 August 2020

(c) Springer Science+Business Media, LLC, part of Springer Nature 2020

\begin{abstract}
Outside the host, viruses will eventually lose their ability to infect cells due to conformational changes that occur to proteins on the viral capsid. In order to undergo a conformational change, these proteins require energy to activate the chemical reaction that leads to the conformational change. In this study, data from the literature is used to calculate the energy required for viral inactivation for a variety of different viruses by means of the Arrhenius equation. We find that some viruses (rhinovirus, poliovirus, human immunodeficiency virus, Alkhumra hemorrhagic fever virus, and hepatitis A virus) have high inactivation energies, indicative of breaking of a chemical double bond. We also find that several viruses (respiratory syncytial virus, poliovirus, and norovirus) have nonlinear Arrhenius plots, suggesting that there is more than a single pathway for inactivation of these viruses.
\end{abstract}

Keywords Viral inactivation $\cdot$ Arrhenius equation $\cdot$ Activation energy $\cdot$ Viral decay $\cdot$ Mathematical model

\section{Introduction}

Viruses cause a variety of diseases that range from mild or asymptomatic to severe illnesses that can lead to death. Viruses have a nucleic acid genome, either RNA or DNA, that is surrounded by a lipid capsid containing surface receptors that allow the virus to interact with cells. Viral inactivation occurs when the proteins on the surface of the particle change shape, and as a result, lose their ability to function properly, removing their ability to infect cells (Keller et al. 2018; Snyder et al. 2019; Whitehurst et al. 2007). Understanding viral inactivation is important for determining transmission of viruses (Yue et al. 2019; Pinon and Vialette 2018; Predmore et al. 2015), but also plays a role in vaccine development (Dumard et al. 2017; Silva et al. 2015).

One key to understanding viral inactivation is to examine the dynamics of the conformational change that occurs

Electronic supplementary material The online version of this article (https://doi.org/10.1007/s12560-020-09439-9) contains supplementary material, which is available to authorized users.

Hana M. Dobrovolny

h.dobrovolny@tcu.edu

1 Department of Chemistry, Wingate University, Hendersonville, NC, USA

2 Department of Physics and Astronomy, Texas Christian University, Fort Worth, TX, USA during inactivation. Instead of studying conformational changes during viral inactivation using the entire virus, some studies investigate conformational changes on isolated proteins (Grgacic and Schaller 2000; Silnikov and Plotnikov 2018), on empty capsids (Poryvaev 1995; Moore et al. 2016), or on virus-like particles (Ausar et al. 2006; Snyder et al. 2019). An alternative approach is to use energy considerations to infer the types of structural changes that occur during viral inactivation (Cartwright et al. 1956; Barnes et al. 1969; Burge et al. 1983). This method uses Arrhenius plots, which relate decay constants to temperature, to determine the energy required to initiate the chemical reaction that causes loss of viral infectivity (Burge et al. 1983; Madani et al. 2014; Bozkurt et al. 2015; Allison et al. 1985). The value of this activation energy can provide insight into the type of chemical bond being altered (Allison et al. 1985). While inactivation energy has been calculated for a few viruses (Allison et al. 1985; Madani et al. 2014; Bozkurt et al. 2015; de Flora 1978), there has not been a comparison of inactivation energies of different viruses. Such a comparison could help determine whether there are commonalities in the mechanisms of loss of infectivity of different viruses.

A better understanding of the energy requirements needed for viral inactivation has practical implications. Viral inactivation is crucial for keeping food and blood products safe $(\mathrm{Li}$ et al. 2015; Ainley and Hewitt 2018). Knowing inactivation energies of different viruses can help in optimizing thermal 
treatments of food or blood products to eliminate viral pathogens (Huangfu et al. 2016). Inactivated viral particles are also sometimes used as vaccines (Delrue et al. 2012), so ensuring that all virus in the sample has been inactivated is crucial for vaccine safety. Conversely, live attenuated vaccines require that the virus is thermostable and does not become inactivated during transport and storage (Hansen et al. 2016; Clenet 2018).

Understanding the processes underlying viral loss of infectivity is also important for constructing accurate mathematical models of the infection process. Most viral kinetics models assume exponential decay of virus (Baccam et al. 2006; Perelson et al. 1996; González-Parra and Dobrovolny 2015; González-Parra et al. 2018), but recent studies suggest that this might not be an accurate assumption for all viruses (Beauchemin et al. 2019; Ailavadi et al. 2019; Bozkurt et al. 2015). Incorrect modeling of the mechanism of viral decay could lead to erroneous predictions of viral time courses, particularly when using models to estimate antiviral efficacy from viral decay rates (Palmer et al. 2017; Cardozo et al. 2020, 2017). Thus a better understanding of the mechanisms underlying loss of infectivity for different viruses is important for developing accurate viral kinetics models.

In this study, we collected viral inactivation data for a variety of viruses using data drawn from the literature. We calculated viral decay rates and used the Arrhenius equation to calculate the inactivation energy for each virus. We find that there is a wide range of inactivation energies for the different viruses and that some viruses appear to have multiple inactivation pathways.

\section{Results}

\section{Viruses with Multiple Data Sets}

We found multiple data sets for several viruses including influenza, respiratory syncytial virus (RSV), coronavirus, hepatitis, and norovirus. Details of the viruses and inactivation experiments are presented in Tables 1 and 2, respectively. Graphs of the linear fits to the viral inactivation data as well as the resulting parameter estimates are contained in the supplemental material. The slopes are used to generate Arrhenius plots that are also included in the supplemental material along with linear fits and parameter estimates. The slopes of the Arrhenius plots are used to calculate inactivation energy, as described in Methods. Inactivation energies for the different viruses are shown in Fig. 1.

\section{Influenza}

Influenza virus causes a respiratory infection that can lead to severe illness and death (Sarda et al. 2019). Influenza's animal reservoir is in birds (Bodewes and Kuiken 2018) and various strains have jumped from birds to humans over the years (Horman et al. 2018). One possible mode of such transmission is through the environment (Rabinowitz et al. 2010), so understanding how easily different strains of influenza decay can give insight into which strains are more likely to be transmitted through the environment. We found five papers that described influenza inactivation data for different strains of influenza. One of these papers, by Handel et al. (2013), presented viral clearance rate as a function of temperature rather than raw viral load measurements from mock infections.

Inactivation energy for different strains of influenza virus is shown in Fig. 1 (top left). The different strains of influenza have similar inactivation energies with a strain of H6N2 (Graiver) having the smallest energy of $6.01 \times 10^{-20} \pm 0.15 \times 10^{-20} \mathrm{~J}$ and a strain of H1N1 having the largest energy of $1.94 \times 10^{-19} \pm 0.59 \times 10^{-19} \mathrm{~J}$. These energies are suggestive of single chemical bonds which have typical binding energies in the range of $\sim 0.5-1.5 \times 10^{-19} \mathrm{~J}$. It is interesting to note that a different strain of H6N2 (Lebarbenchon) had a higher energy, although since the data is from two different studies, it is unclear whether this difference is due to differences in structure between the two strains or due to differences in experimental conditions. The Arrhenius plots for influenza are generally linear (supplemental material), suggesting the Arrhenius model is a reasonable assumption for the underlying dynamics of influenza virus inactivation.

\section{Respiratory Syncytial Virus}

RSV also causes a respiratory illness that is typically mild in adults, but can be severe in infants and the elderly (Walsh et al. 2013; Stein et al. 2017). There is currently no vaccine for RSV (Vekemans et al. 2019) and one of the stumbling blocks is the stability of the virus itself (Beugeling et al. 2019), so there is interest in understanding inactivation kinetics of RSV. We found three studies with the type of data described in methods.

Inactivation energies for RSV are shown in Fig. 1 (top right). The inactivation energies for RSV are generally about an order of magnitude lower than those for influenza, ranging from $3.8 \times 10^{-21} \pm 1.5 \times 10^{-20} \mathrm{~J}$ to $5.1 \times 10^{-20} \pm 2.4 \times 10^{-20} \mathrm{~J}$, with the exception of the data from Hambling et al. which gives an inactivation energy of $1.58 \times 10^{-10} \pm 0.75 \times 10^{-19} \mathrm{~J}$. These lower energies suggest that RSV is easier to inactivate and could help explain the difficulty in developing RSV vaccines that remain active over long periods of time. It is also notable that the Hambling and Rechsteiner Arrhenius plots are not particularly linear (the DeFord data only has three data points, making it difficult to judge linearity), suggesting inactivation of RSV 
Table 1 Virus details for influenza, RSV, coronavirus, hepatitis, and norovirus experiments

\begin{tabular}{|c|c|c|c|c|}
\hline Paper & Virus & DNA/RNA & Envelope & Diameter (nm) \\
\hline \multicolumn{5}{|l|}{ Influenza } \\
\hline Davidson & A/Israel/1525/06 (H9N2) & $\begin{array}{l}\text { Segmented, -ssRNA (Bou- } \\
\text { vier and Palese 2008) }\end{array}$ & $\begin{array}{l}\text { E (Bouvier and Palese } \\
\text { 2008) }\end{array}$ & 85-120 (Roy et al. 2000) \\
\hline Graiver & $\begin{array}{l}\mathrm{A} / \mathrm{CK} / \mathrm{CA} / 101247 / 01 \\
\text { (H6N2) }\end{array}$ & Segmented, -ssRNA & $\mathrm{E}$ & $85-120$ \\
\hline Handel & $\begin{array}{l}\text { A/green-winged teal/ } \\
\text { LA/213GW/87 (H1N1) }\end{array}$ & Segmented, -ssRNA & $\mathrm{E}$ & $85-120$ \\
\hline Handel & $\begin{array}{l}\text { A/blue-winged teal/ } \\
\text { TX/421717/01 (H2N4) }\end{array}$ & Segmented, -ssRNA & $\mathrm{E}$ & $85-120$ \\
\hline Handel & $\begin{array}{l}\text { A/mallard/MN/199036/99 } \\
\text { (H3N2) }\end{array}$ & Segmented, -ssRNA & $\mathrm{E}$ & $85-120$ \\
\hline Handel & $\begin{array}{l}\text { A/mallard/MN/199057/99 } \\
\text { (H4N6) }\end{array}$ & Segmented, -ssRNA & $\mathrm{E}$ & $85-120$ \\
\hline Handel & $\begin{array}{l}\mathrm{A} / \mathrm{mallard} / \mathrm{MN} / 346250 / 00 \\
(\mathrm{H} 5 \mathrm{~N} 2)\end{array}$ & Segmented, -ssRNA & $\mathrm{E}$ & $85-120$ \\
\hline Handel & $\begin{array}{l}\text { A/ring-billed gull/ } \\
\text { GA/421733/01 (H6N4) }\end{array}$ & Segmented, -ssRNA & $\mathrm{E}$ & $85-120$ \\
\hline Handel & $\begin{array}{l}\text { A/Northern shoveler/ } \\
\text { NC/1523546/05 (H7N6) }\end{array}$ & Segmented, -ssRNA & $\mathrm{E}$ & $85-120$ \\
\hline Handel & $\begin{array}{l}\text { A/Northern pintail/ } \\
\text { TX/421716/01 (H8N4) }\end{array}$ & Segmented, -ssRNA & $\mathrm{E}$ & $85-120$ \\
\hline Handel & $\begin{array}{l}\text { A/ruddy turnstone/ } \\
\text { NJ/1016409/03 (H9N2) }\end{array}$ & Segmented, -ssRNA & $\mathrm{E}$ & $85-120$ \\
\hline Handel & $\begin{array}{l}\text { A/red knot/DE/AI001329/00 } \\
\text { (H10N7) }\end{array}$ & Segmented, -ssRNA & $\mathrm{E}$ & $85-120$ \\
\hline Handel & $\begin{array}{l}\text { A/dunlin/DE/AI00-1459/00 } \\
\text { (H11N6) }\end{array}$ & Segmented, -ssRNA & $\mathrm{E}$ & $85-120$ \\
\hline Handel & $\begin{array}{l}\text { A/mallard/MN/355788/00 } \\
\text { (H12N5) }\end{array}$ & Segmented, -ssRNA & $\mathrm{E}$ & $85-120$ \\
\hline Lebarbenchon & $\begin{array}{l}\text { A/mallard/MN/Sg-00169/07 } \\
\text { (H3N8) }\end{array}$ & Segmented, -ssRNA & $\mathrm{E}$ & $85-120$ \\
\hline Lebarbenchon & $\begin{array}{l}\text { A/mallard/MN/Sg-00219/07 } \\
\text { (H4N8) }\end{array}$ & Segmented, -ssRNA & $\mathrm{E}$ & $85-120$ \\
\hline Lebarbenchon & $\begin{array}{l}\text { A/mallard/MN/Sg-00170/07 } \\
\text { (H6N1) }\end{array}$ & Segmented, -ssRNA & $\mathrm{E}$ & $85-120$ \\
\hline Lebarbenchon & $\begin{array}{l}\text { A/mallard/MN/Sg-00107/07 } \\
\text { (H6N2) }\end{array}$ & Segmented, -ssRNA & $\mathrm{E}$ & $85-120$ \\
\hline Lebarbenchon & $\begin{array}{l}\text { A/green-winged teal/MN/ } \\
\text { Sg-00197/07 (H6N8) }\end{array}$ & Segmented, -ssRNA & $\mathrm{E}$ & $85-120$ \\
\hline Paek & $\begin{array}{l}\text { A/chicken/Korea/ES/03 } \\
\text { (H5N1) }\end{array}$ & Segmented, -ssRNA & $\mathrm{E}$ & $85-120$ \\
\hline Paek & $\begin{array}{l}\text { A/chicken/Korea/IS/06 } \\
\text { (H5N1) }\end{array}$ & Segmented, -ssRNA & $\mathrm{E}$ & $85-120$ \\
\hline Paek & $\begin{array}{l}\text { A/chicken/Korea/Gimje/08 } \\
\text { (H5N1) }\end{array}$ & Segmented, -ssRNA & $\mathrm{E}$ & $85-120$ \\
\hline \multicolumn{5}{|l|}{ RSV } \\
\hline DeFord & A2-mKate2 & -ssRNA (Lee et al. 2012) & E (Lee et al. 2012) & 120-200 (Bachi 1973) \\
\hline DeFord & A2-mKate2-line19F & -ssRNA & $\mathrm{E}$ & $120-200$ \\
\hline DeFord & $\begin{array}{l}\text { A2-mKate2-(A/1998/1221) } \\
\text { GF }\end{array}$ & -ssRNA & $\mathrm{E}$ & $120-200$ \\
\hline DeFord & $\begin{array}{l}\text { A2-mKate2-(Riyadh } \\
\text { A/91/2009)GF }\end{array}$ & -ssRNA & $\mathrm{E}$ & $120-200$ \\
\hline DeFord & A2-mKate2-(TX11-56)GF & -ssRNA & $\mathrm{E}$ & $120-200$ \\
\hline Hambling & A2 Long & -ssRNA & $\mathrm{E}$ & $120-200$ \\
\hline
\end{tabular}


Table 1 (continued)

\begin{tabular}{|c|c|c|c|c|}
\hline Paper & Virus & DNA/RNA & Envelope & Diameter (nm) \\
\hline Rechsteiner & A2 Long & -ssRNA & $\mathrm{E}$ & $120-200$ \\
\hline \multicolumn{5}{|l|}{ Coronavirus } \\
\hline Casanova & TGEV & $\begin{array}{l}\text { +ssRNA (Rasschaert et al. } \\
\text { 1987) }\end{array}$ & E (Rasschaert et al. 1987) & 100-150 (Martins et al. 2013) \\
\hline Casanova & MHV & $\begin{array}{l}\text { +ssRNA (Hui Chang et al. } \\
\text { 2011) }\end{array}$ & E (Hui Chang et al. 2011) & $\sim 100$ (Liang et al. 1995) \\
\hline Chan & SARS HKU39849 & $\begin{array}{l}\text { +ssRNA (Ksiazek et al. } \\
\text { 2003) }\end{array}$ & E (Ksiazek et al. 2003) & 80-140 (Ksiazek et al. 2003) \\
\hline Daniel & MHV-A 59 & +ssRNA & $\mathrm{E}$ & $\sim 100$ \\
\hline Laude & TGEV & + ssRNA & $\mathrm{E}$ & $100-150$ \\
\hline \multicolumn{5}{|l|}{ Hepatitis } \\
\hline Ciesek & HCV Luc-Jc1 & $\begin{array}{l}\text { +ssRNA (Echeverria et al. } \\
\text { 2015) }\end{array}$ & E (Echeverria et al. 2015) & $\begin{array}{l}\text { 55-65 (Dubuisson and Cosset } \\
\text { 2014) }\end{array}$ \\
\hline de Flora & $\mathrm{HBV}$ & $\begin{array}{l}\text { partially dsDNA } \\
\text { (McNaughton et al. 2019) }\end{array}$ & E (Howard 1995) & 42 (Kaito et al. 2006) \\
\hline Gibson and Schwab & HAV HM-175 & $\begin{array}{l}\text { ssRNA (Cristina and Costa- } \\
\text { Mattioli 2007) }\end{array}$ & $\begin{array}{l}\text { quasi-E (McKnight et al. } \\
\text { 2017) }\end{array}$ & $\begin{array}{l}\text { 25-32 (Siegl and Frosner } \\
\text { 1987) }\end{array}$ \\
\hline Johne & HEV 47832c & $\begin{array}{l}\text { +ssRNA (Ahmad et al. } \\
\text { 2010) }\end{array}$ & NE (Ahmad et al. 2010) & 27-30 (Balayan et al. 1983) \\
\hline Song & HCV JFH-1 & +ssRNA & $\mathrm{E}$ & $55-65$ \\
\hline Than & HBV & partially dsDNA & $\mathrm{E}$ & 42 \\
\hline \multicolumn{5}{|l|}{ Norovirus surrogates } \\
\hline Arthur & Tulane virus & $\begin{array}{l}\text { +ssRNA (Farkas et al. } \\
\text { 2008) }\end{array}$ & NE (Farkas et al. 2008) & 36 (Farkas et al. 2008) \\
\hline Gibson & murine norovirus type I & +ssRNA (Karst et al. 2003) & NE (Karst et al. 2003) & 28-35 (Karst et al. 2003) \\
\hline Seo & murine norovirus & +ssRNA & NE & $28-35$ \\
\hline Tian & Tulane virus & +ssRNA & $\mathrm{NE}$ & 36 \\
\hline
\end{tabular}

$s s$ single strand, $d s$ double strand, $E$ enveloped, $N E$ nonenveloped

'十' = positive sense, '-' = negative sense

is not caused by a simple conformational change in a single protein. A nonlinear Arrhenius plot suggests that there are two inactivation pathways (Vyazovkin 2016).

\section{Coronavirus}

Coronaviruses cause respiratory infections that range from the common cold to more serious illnesses such as severe acute respiratory syndrome (SARS), Middle East respiratory syndrome (MERS), and the recent COVID-19 pandemic (Paules et al. 2020; Corman et al. 2019). While primarily transmitted through respiratory droplets (Kutter et al. 2018), some coronavirus, like the one responsible for COVID-19, have been shown to remain active on surfaces for a long period of time (Kampf et al. 2020), allowing for transmission through contact with the surface. We found four papers describing the thermal inactivation of various coronaviruses: transmissible gastroenteritis virus (TGEV), mouse hepatitis virus (MHV), and the coronavirus responsible for SARS (SARS-CoV). TGEV and MHV, both viruses that infect animals, are considered experimental surrogates for
SARS-CoV (Casanova et al. 2010; Farnsworth et al. 2006; Dellanno et al. 2009).

Inactivation energies of coronaviruses are shown in Fig. 1 (center left). Coronavirus inactivation energies are slightly higher than those of influenza, ranging from $1.187 \times 10^{-19} \pm 0.016 \times 10^{-19} \mathrm{~J}$ to $3.29 \times 10^{-19} \pm 0.24 \times 10^{-19} \mathrm{~J}$. It is not entirely clear if these are single bonds or double bonds-single bonds range from $\sim 0.5-1.5 \times 10^{-19} \mathrm{~J}$ while double bonds are in the range of $\sim 2.0-5.0 \times 10^{-19} \mathrm{~J}$. Coronavirus energies fall in both ranges. Coronavirus Arrhenius plots appear to be linear (supplemental material), suggesting a simple viral inactivation mechanism for this virus family.

\section{Hepatitis}

There are five viruses that can cause different forms of hepatitis (A, B, C, D, \& E). These are not different strains of a single virus, but rather viruses originating from different virus families (Rasche et al. 2019) that all cause inflammation of the liver and can exhibit different clinical 
Table 2 Experimental details of viral inactivation experiments for influenza, RSV, coronavirus, hepatitis, and norovirus

\begin{tabular}{|c|c|c|c|}
\hline Paper & Temperatures $\left({ }^{\circ} \mathrm{C}\right)$ & Medium & Cell culture \\
\hline \multicolumn{4}{|l|}{ Influenza } \\
\hline Davidson et al. (2010) & $37,20,4$ & Allantoic fluid & Embryonating chicken egg \\
\hline Graiver et al. (2009) & $37,21,4$ & Distilled water & MDCK \\
\hline Handel et al. (2013) & $37,32,28,20,17,10,4$ & Distilled water & MDCK \\
\hline Lebarbenchon et al. (2012) & $28,23,17,10,4$ & Distilled water & MDCK \\
\hline Paek et al. (2010) & $30,20,4$ & Allantoic fluid & Chicken embryo fibroblast \\
\hline \multicolumn{4}{|l|}{ RSV } \\
\hline DeFord et al. (2019) & $37,32,4$ & PBS & HEp-2 \\
\hline Hambling (1964) & $55,37,25,4$ & Hanks BBS & HeLa \\
\hline Rechsteiner (1968) & $50,45,40,37,30,20,10,4,0$ & Distilled water & HeLa \\
\hline \multicolumn{4}{|l|}{ Coronavirus } \\
\hline Casanova et al. (2010) TGEV & $40,20,4$ & MEM & Swine testicular \\
\hline Casanova et al. (2010) MHV & $40,20,4$ & MEM & Delayed brain tumor \\
\hline Chan et al. (2011) & $38,33,28$ & MEM & Fetal monkey kidney (FRhK-4) \\
\hline Daniel and Talbot (1987) & $37,22,4$ & MEM & Delayed brain tumor \\
\hline Laude (1981) & $55,51,47,43,39,35,31$ & MEM & Pig kidney $\left(\mathrm{RP}_{\mathrm{D}}\right)$ \\
\hline \multicolumn{4}{|l|}{ Hepatitis } \\
\hline Ciesek et al. (2010) & $37,21,4$ & MEM & Huh7.5 \\
\hline de Flora (1978) & $98,70,56,44,37,20$ & PBS & Radioimmunoassay \\
\hline Gibson and Schwab (2011) & $70,60,50,37$ & PBS & FRhK-4 \\
\hline Johne et al. (2016) & $37,22,4$ & MEM & A549 \\
\hline Song et al. (2010) & $37,22,4$ & Human serum & Huh7-25-CD81 \\
\hline Than et al. (2019) & $37,21,4$ & DMEM & HepAD38 \\
\hline \multicolumn{4}{|l|}{ Norovirus surrogates } \\
\hline Arthur and Gibson (2015) & $72,63,56$ & PBS & LLC-MK2 \\
\hline Gibson and Schwab (2011) & $60,50,37$ & PBS & RAW 264.7 (ATCC TIB-71) \\
\hline Seo et al. (2012) & $85,70,60,50,37,24$ & DMEM & RAW 264.7 (ATCC TIB-71) \\
\hline Tian et al. (2013) & $72,63,56,37$ & M199 & LLC-MK2 \\
\hline
\end{tabular}

manifestations (Su et al. 2002; Chu et al. 2001). Hepatitis A is caused by hepatovirus A (HAV), a single-stranded RNA virus from the picornavirus family (Cristina and Costa-Mattioli 2007). HAV does not have a traditional viral envelope, but the viral capsid is released in a quasi-envelope made of membranous vesicles (McKnight et al. 2017). Hepatitis B is an unusual reverse-transcription, partially double stranded DNA virus-one DNA strand contains the full genome, while a second shorter strand contains only half to one third of the nucleotides (McNaughton et al. 2019). $\mathrm{HBV}$ is an enveloped virus from the hepadnavirus family (Howard 1995). Hepatitis C is caused by an enveloped, single-stranded, positive sense, RNA virus of the Flavivirus family (Echeverria et al. 2015). Hepatitis D is caused by the hepatitis delta virus (HDV) that cannot cause infection on its own, but requires the presence of HBV (Abou-Jaoude and Sureau 2007). HDV is an enveloped, negative sense, single-stranded RNA virus (Elena et al. 1991). Hepatitis E is caused by the hepatitis E virus (HEV), a nonenveloped, positive sense, single-stranded RNA virus of the hepevirus family (Ahmad et al. 2010). Hepatitis A and E are primarily transmitted through food and water contamination (Miranda and Schaffner 2019), so there is interest in understanding how long they remain in the environment. We found six papers with sufficient data to assess the thermal stability of various hepatitis viruses, one of which (de Flora) only included decay rates as a function of temperature rather than viral load measurements of mock infections.

Inactivation energies for hepatitis viruses are presented in Fig. 1 (center right). Hepatitis viruses show a large range of inactivation energies from $2.79 \times 10^{-20} \pm 0.29 \times 10^{-20} \mathrm{~J}$ for HEV to $3.28 \times 10^{-19} \pm 0.32 \times 10^{-19} \mathrm{~J}$ for HAV. The HAV inactivation energy is suggestive of a double bond, while the remaining hepatitis viruses are more in line with single bond energies. Studies have shown that HAV can persist for several days on food and surfaces (Leblanc et al. 2019; Cook et al. 2018), which is in line with the higher energy required for inactivation of this virus. The Arrhenius plots for all hepatitis viruses are linear indicating a single chemical reaction pathway causes inactivation of the virus. 

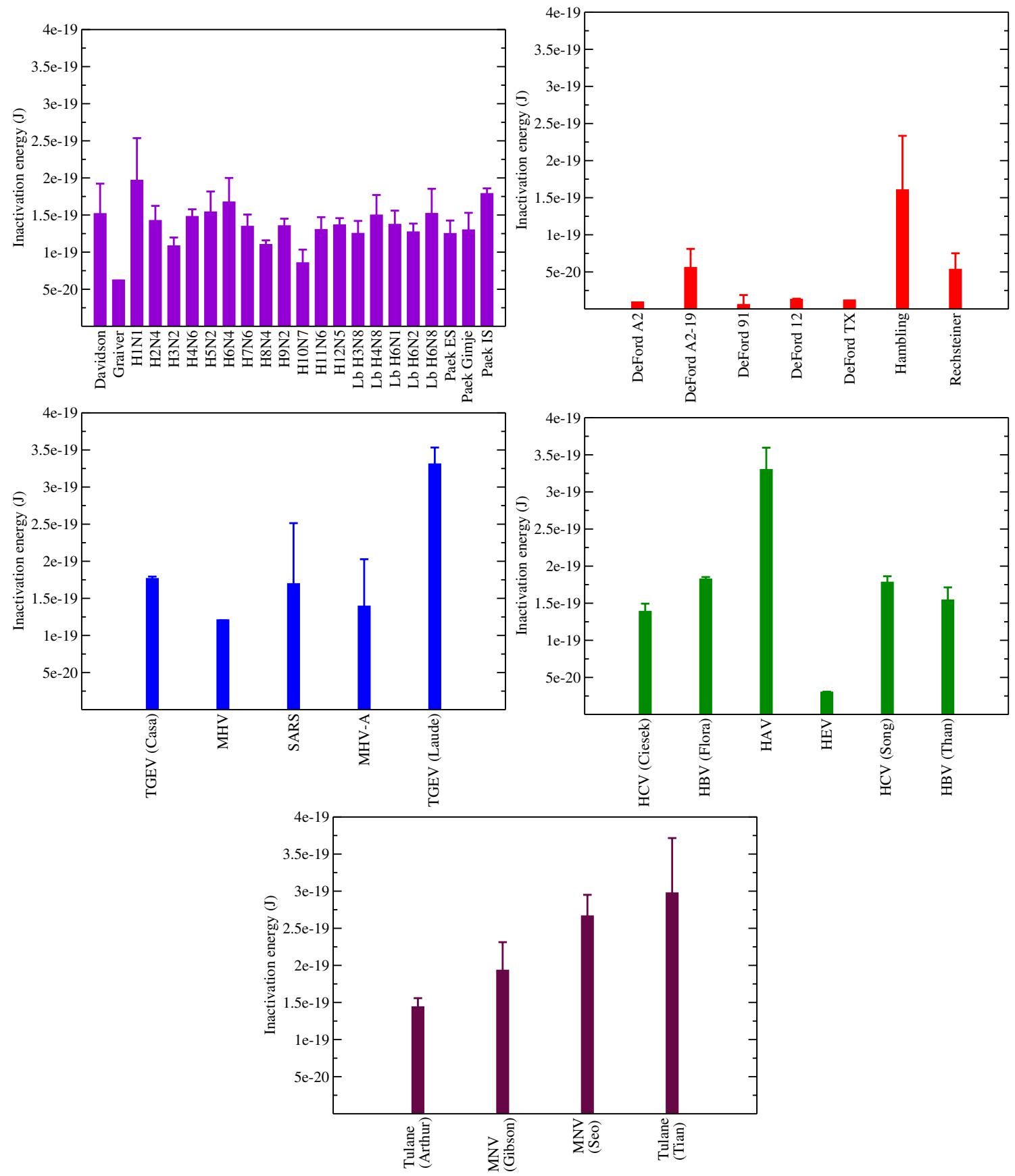

Fig. 1 Energy required for the conformational change leading to viral inactivation for different viruses: (top left) influenza virus, (top right) respiratory syncytial virus, (center left) coronavirus, (center right) hepatitis, (bottom) norovirus surrogates. Strain details can be found in Table 1

\section{Norovirus Surrogates}

Noroviruses cause serious gastrointestinal illnesses (Sell and Dolan 2018) and are commonly found in the environment (Goh et al. 2019). Due to the high infectivity of human norovirus (Manuel et al. 2018), Tulane virus and mouse norovirus are often used as surrogates for experimental investigations (Farkas 2015; Hirneisen and Kniel 2013; Belardo et al.
2008). We found four papers using norovirus surrogates with sufficient data for our analysis.

Inactivation energies for norovirus surrogates are shown in Fig. 1 (bottom). The inactivation energies for these viruses are generally a little higher than the inactivation energies for most of the other viruses we examined, ranging from $1.42 \times 10^{-19} \pm 0.14 \times 10^{-19} \mathrm{~J}$ to $2.95 \times 10^{-19} \pm 0.76 \times 10^{-19} \mathrm{~J}$, suggestive of a double bond 
being altered. While the data is limited, there is some evidence that the Arrhenius plots are not linear for these viruses, suggesting more complex mechanisms for inactivation of noroviruses.

\section{Other Viruses}

We found experimental data for a variety of other viruses, listed in Table 3. Details of the inactivation experiments are given in Table 4. The fits to this data, along with the Arrhenius plots and their fits are included in the supplemental material. The inactivation energies are shown in Fig. 2. Four of the viruses have notably high inactivation energies; rhinovirus, poliovirus (Dimmock data), HIV, and Alkhumra hemorrhagic fever virus all have energies of $3 \times 10^{-19} \mathrm{~J}$ or higher, indicating a change in a double bond. The remaining viruses have inactivation energies near $2 \times 10^{-19} \mathrm{~J}$ or below, suggesting changes in single bonds lead to inactivation of these viruses. Interestingly, there are two data sets for poliovirus that give very different estimates of inactivation energy. The Dimmock data gives a high inactivation energy while the Snowden data gives a low inactivation energy. The Arrhenius plot for the Dimmock poliovirus is not linear, but has a larger slope at higher temperatures. The Snowden data uses low temperature data $\left(25^{\circ} \mathrm{C}\right.$ and below), so is on the more shallow part (lower slope) of this curve, so this is a possible reason for the discrepancy.

\section{Discussion}

While there are other environmental conditions that will cause loss of viral infectivity, such as changes in $\mathrm{pH}$ (Nims and Zhou 2016), salinity (Carratala et al. 2013), and UV light (Totaro Garcia and Monte Barardi 2019), in this manuscript, we considered only temperature because it allows us to find the inactivation energy through use of the Arrhenius equation. We found the inactivation energies for a variety of viruses. The value of the inactivation energy tells us something about the type of chemical bond broken during the inactivation process. The majority of the viruses had energies below $1.5 \times 10^{-19} \mathrm{~J}$ which is suggestive of a single bond being changed during the inactivation process. Rhinovirus, poliovirus, HIV, AHFV, and HAV all had high inactivation energies, indicating a double bond was likely being altered. Coronavirus inactivation energies were not clear-cut, and could be either single or double bonds.

The Arrhenius equation can be used to describe viral inactivation only if there is a single protein undergoing a conformational change during the process. We found that most of

Table 3 Virus details for other viruses

\begin{tabular}{|c|c|c|c|c|}
\hline Paper & Virus & DNA/RNA & Envelope & Diameter (nm) \\
\hline Dimmock & Rhinovirus HGP & +ssRNA (Kennedy et al. 2012) & NE (Kennedy et al. 2012) & 30 (Rossmann et al. 1985) \\
\hline Dimmock & Poliovirus type I LSc $2 \mathrm{ab}$ & +ssRNA (Hogle 2002) & NE (Hogle 2002) & $\begin{array}{l}\text { 30 (Schaffer and Schwerdt } \\
1959)\end{array}$ \\
\hline Gibson & Feline calicivirus F9 & $\begin{array}{l}\text { +ssRNA (Lee and Gillespie } \\
\text { 1973) }\end{array}$ & NE (Lee and Gillespie 1973) & 30-40 (Zhou et al. 1994) \\
\hline Gosting & Hematopoietic necrosis virus & -ssRNA (Hill et al. 1975) & E (Hill et al. 1975) & $\begin{array}{l}\text { 45-100 (diameter), 100-430 } \\
\text { (length) (Hill et al. 1975) }\end{array}$ \\
\hline Gosting & Pancreatic necrosis virus & $\begin{array}{l}\text { Segmented, dsRNA (Sano et al. } \\
\text { 1992) }\end{array}$ & NE (Sano et al. 1992) & 55 (Moss and Gravell 1969) \\
\hline Lo & $\begin{array}{l}\text { Poliomyelitis type I (Mahoney) } \\
\text { virus }\end{array}$ & +ssRNA (Hogle 2002) & NE (Hogle 2002) & $\begin{array}{l}\sim 30 \text { (Schaffer and Schwerdt } \\
1959 \text { ) }\end{array}$ \\
\hline Lo & Echovirus-6 (D’Amori) & $\begin{array}{l}\text { +ssRNA (Seal and Jamison } \\
\text { 1984) }\end{array}$ & NE (Seal and Jamison 1984) & 20-30 (Nyangao et al. 2006) \\
\hline Lo & Coxsackie B-5 (Faulkner) virus & +ssRNA (Bowles et al. 1986) & NE (Bowles et al. 1986) & 20-30 (Sohal and Burch 1969) \\
\hline Madani & AHFV/997/NJ/09/SA & +ssRNA (Madani et al. 2012) & E (Madani et al. 2017) & 40 (Madani et al. 2017) \\
\hline McDougal & $\begin{array}{l}\text { Human T lymphotropic virus } \\
\text { type III }\end{array}$ & $\begin{array}{l}\text { Diploid, ssRNA (Poiesz et al. } \\
\text { 1980) }\end{array}$ & E (Poiesz et al. 1980) & 100-110 (Poiesz et al. 1980) \\
\hline Meng & Simian rotavirus SAll & dsRNA (Patton 1986) & NE (Prasad et al. 1988) & $\sim 75$ (Prasad et al. 1988) \\
\hline Snowden & Poliovirus type I & +ssRNA (Hogle 2002) & NE (Hogle 2002) & $\begin{array}{l}\text { 30 (Schaffer and Schwerdt } \\
1959 \text { ) }\end{array}$ \\
\hline Trent & CTFV Florian strain & $\begin{array}{l}\text { Segmented, dsRNA (Green } \\
\text { 1970) }\end{array}$ & $\begin{array}{l}\text { NE (Oshiro and Emmons } \\
1968)\end{array}$ & 80 (Oshiro and Emmons 1968) \\
\hline Ward & Echovirus type 12 & $\begin{array}{l}\text { +ssRNA (Seal and Jamison } \\
\text { 1984) }\end{array}$ & NE (Seal and Jamison 1984) & 20-30 (Nyangao et al. 2006) \\
\hline Ward & Rotavirus SA11 & dsRNA (Patton 1986) & NE (Prasad et al. 1988) & $\sim 75$ (Prasad et al. 1988) \\
\hline
\end{tabular}


Table 4 Experimental details for other virus

\begin{tabular}{llll}
\hline Paper & Temperatures $\left({ }^{\circ} \mathrm{C}\right)$ & Medium & Cell culture \\
\hline Dimmock (1967) (rhino) & $55,50,45,40,35,30,20$ & MEM & KB \\
Dimmock (1967) (polio) & $50,47,45,40,35,30,20$ & MEM & HeLa \\
Gibson and Schwab (2011) & $60,50,37$ & PBS & CrFK \\
Gosting and Gould (1981) (IHNV) & $38,32,28,22,8$ & MEM & EPC \\
Gosting and Gould (1981) (IPNV) & $60,50,37.5$ & MEM & BF-2 \\
Lo et al. (1976) (polio) & $25,15,4$ & Water & BGM \\
Lo et al. (1976) (echo) & $25,15,4$ & Water & BGM \\
Lo et al. (1976) (cox) & $25,15,4$ & Water & BGM \\
Madani et al. (2014) & $60,56,50,45$ & MEM & LLC-MK2 \\
McDougal et al. (1985) & $60,56,50,45,37$ & RPMI & PHA-stimu- \\
& & & lated lym- \\
& $56,37,20,4$ & MEM & phocytes \\
Meng et al. (1987) & $25,15,5$ & PBS & BGM \\
Snowden et al. (1989) & $56,45,37,25$ & Hank's BBS & Earle's L-cell \\
Trent and Scott (1966) & $37,29,23,16,4$ & Distilled water & RD \\
Ward et al. (1986) (echo) & $37,29,23,16,4$ & Distilled water & MA-104 \\
Ward et al. (1986) (rota) & &
\end{tabular}

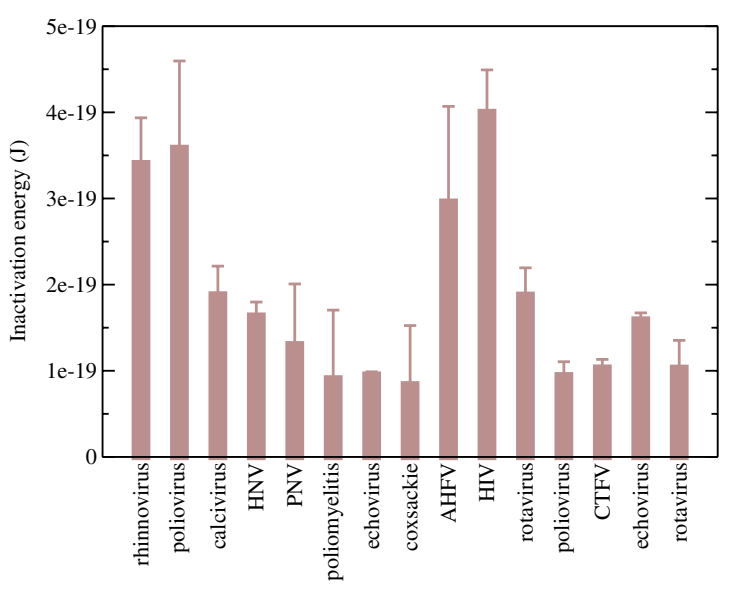

Fig. 2 Energy required for the conformational change leading to viral inactivation for different viruses

the viruses had data that was linear in the range of temperatures used in the experiments (indicated by $R$ values close to 1). However, most viruses are likely to show multiple pathways for viral inactivation. For example, feline calicivirus was found to have at least two inactivation mechanisms; one involving a reaction with singlet oxygen, and one conformational change induced by other reactive oxygen and nitrogen species (Aboubakr et al. 2016). The MS2 bacteriophage was also found to have two different chemical reactions that led to inactivation of the virus (Wigginton et al. 2010). It is surprising then that we find so many linear Arrhenius plots. One reason for this is that many experiments used only three temperatures, making it difficult to detect nonlinearities in the Arrhenius plot. Another possibility is that there is a dominant reaction in the temperature ranges considered in these experiments, making the Arrhenius plot in that range linear. In order to detect nonlinearities and multiple inactivation pathways, more temperatures over a wider range will need to be used in inactivation experiments.

The majority of viruses investigated here had linear Arrhenius plots, the exceptions being RSV, norovirus, and poliovirus. There is already some evidence that viral decay for these viruses differs from that of other viruses (Beauchemin et al. 2019; Ailavadi et al. 2019; Tamrakar et al. 2017; Incardona 1974). These studies suggest that decay for these viruses is not a simple exponential, with norovirus being modeled by a Weibull function (Ailavadi et al. 2019), RSV decay being modeled best by a two-population model (Beauchemin et al. 2019), and poliovirus being modeled by either a damped exponential (Tamrakar et al. 2017) or biphasic decay (Incardona 1974). Some of these models suggest multiple pathways for viral inactivation. In particular, the two-population model (Beauchemin et al. 2019) could describe a virus population consisting of a wild-type virus and one whose surface proteins are more or less resistant to thermal inactivation (Keller et al. 2018). There are a number of different models that can be used to describe viral decay (Dean et al. 2020; Fischer et al. 2004) and there does not seem to be an obvious best mathematical description of viral inactivation for all viruses.

One limitation of this study is the limited data. The majority of data we found in the literature consisted of measurements of viral inactivation at only three or four temperatures. This limits our ability to judge whether the Arrhenius assumption is reasonable, since it is difficult to judge whether the Arrhenius plots are linear with so few 
temperature points. Another limitation is using a small range of temperatures, thereby getting an incomplete picture of the Arrhenius plots. Some of the data we collected clearly have nonlinear Arrhenius plots, and biphasic Arrhenius plots have also been observed for some viruses (Burge et al. 1983). This could potentially lead to an incorrect value for the inactivation energy as might have been the case for the low poliovirus inactivation energy found for the Snowden data which used temperatures below $25^{\circ} \mathrm{C}$. Viral titer measurements might also be a source of error in these experiments (LaBarre and Lowy 2001), particularly at later time points when virions might have settled into aggregates that form single plaques in the titration assay. Finally, our ability to effectively compare the inactivation energies for different viruses is limited by the inconsistency in experimental conditions. Viral decay is known to be affected by not only temperature, but other environmental factors such as $\mathrm{pH}$ (DeFord et al. 2019; Randazzo et al. 2017), relative humidity (Yeargin et al. 2016), and pressure (Daher et al. 2017).

\section{Materials and Methods}

\section{Mock Infection Experiments}

Mock infection experiments start with some amount of initial viral inoculum placed in a container where there are no cells for the virus to infect. Infectious viral titer measurements are then taken over several hours or days to determine the loss of viral infectivity over time. We searched the literature for studies of viral inactivation using mock infection experiments at different temperatures. We required a minimum of 3 time points at each temperature to allow for measurement of the viral decay rate, as well as an estimate of the error in the measurement; and a minimum of 3 different temperatures. We found 30 papers with such experiments using a variety of different viruses (Table 5). Data was extracted from figures using WebPlotDigitizer. Details of the medium used
Table 5 Sources of data used in this study

\begin{tabular}{|c|c|c|}
\hline Article & Virus & Figure \\
\hline Davidson et al. (2010) & Influenza & 1,2 \\
\hline Graiver et al. (2009) & Influenza & 1 \\
\hline Handel et al. (2013) & Influenza & 3 \\
\hline Lebarbenchon et al. (2012) & Influenza & 3 \\
\hline Paek et al. (2010) & Influenza & 1 \\
\hline DeFord et al. (2019) & RSV & 4 \\
\hline Hambling (1964) & RSV & $2,3,4,5$ \\
\hline Rechsteiner (1968) & RSV & 1,2 \\
\hline Casanova et al. (2010) & TGEV \& MHV & $1,2,3$ \\
\hline Chan et al. (2011) & SARS & 2 \\
\hline Daniel and Talbot (1987) & Murine hepatitis & 3 \\
\hline Laude (1981) & TGEV & 1 \\
\hline Ciesek et al. (2010) & Hepatitis C & 1 \\
\hline de Flora (1978) & Hepatitis B & 2 \\
\hline Gibson and Schwab (2011) & Hepatitis A, norovirus, calicivirus & 1 \\
\hline Johne et al. (2016) & Hepatitis E & 2 \\
\hline Song et al. (2010) & Hepatitis C & 1 \\
\hline Than et al. (2019) & Hepatitis B & 1 \\
\hline Arthur and Gibson (2015) & Tulane & 1 \\
\hline Seo et al. (2012) & norovirus & 1 \\
\hline Tian et al. (2013) & Tulane & 1 \\
\hline Dimmock (1967) & Rhinovirus \& poliovirus & 1 \\
\hline Gosting and Gould (1981) & Hematopoietic necrosis virus, pancreatic necrosis virus & 1,2 \\
\hline Lo et al. (1976) & Poliomyelitis virus, echovirus, coxsackie virus & Tables $1,2,3$ \\
\hline Madani et al. (2014) & Alkhumra hemorrhagic fever virus & 1 \\
\hline McDougal et al. (1985) & HIV & 1 \\
\hline Meng et al. (1987) & Rotavirus & Table 2 \\
\hline Snowden et al. (1989) & Poliovirus & 2 \\
\hline Trent and Scott (1966) & Colorado tick fever virus & 1 \\
\hline Ward et al. (1986) & Echovirus, rotavirus & 2 \\
\hline
\end{tabular}


in each experiment, temperatures at which measurements were made, and the cell culture used to measure infectivity are included in tables in the results section.

\section{Data Analysis}

Viral clearance rate was determined by linear regression of $\log _{10}$ of virus as a function of time. Linear regression was performed using the pol yfit function in the numpy package of python. The slope estimated from this fit is the viral clearance rate.

Our assumption is that a single conformational change in a viral protein leads to inactivation of the virus (Vyazovkin 2016). Under this assumption, the temperature dependence of the viral clearance rate should be given by the Arrhenius equation,

$c=c_{\max } e^{-\frac{E_{\mathrm{a}}}{k_{\mathrm{B}} T}}$,

where $c$ is the viral clearance rate, $E_{\mathrm{a}}$ is the energy required to inactivate a single virion, $k_{\mathrm{B}}$ is the Boltzmann constant, $c_{\text {max }}$ is the maximum clearance rate, and $T$ is temperature in Kelvin. This function was also fit using linear regression of $\ln (c)$ and $1 / T$. The slope of the fitted line is $E_{\mathrm{a}} / k_{\mathrm{B}}$, so we can find the inactivation energy by multiplying slope by the Boltzmann constant.

Acknowledgements This work was supported by NSF REU grants PHY-1358770 \& PHY-1659444.

\section{Compliance with Ethical Standards}

Conflicts of interest The authors declare that they have no conflict of interest.

\section{References}

Abou-Jaoude, G., \& Sureau, C. (2007). Entry of hepatitis delta virus requires the conserved cysteine residues of the hepatitis $\mathrm{B}$ virus envelope protein antigenic loop and is blocked by inhibitors of thiol-disulfide exchange. Journal of Virology, 81(23), 1305713066. https://doi.org/10.1128/JVI.01495-07.

Aboubakr, H. A., Gangal, U., Youssef, M. M., Goyal, S. M., \& Bruggeman, P. J. (2016). Inactivation of virus in solution by cold atmospheric pressure plasma: Identification of chemical inactivation pathways. Journal of Physics D, 49(20), 204001. https://doi. org/10.1088/0022-3727/49/20/204001.

Ahmad, I., Holla, R. P., \& Jameel, S. (2010). Molecular virology of hepatitis E virus. Virus Research, 202(5), 681-689. https://doi. org/10.1016/j.virusres.2011.02.011.

Ailavadi, S., Davidson, P. M., Morgan, M. T., \& D'Souza, D. H. (2019). Thermal inactivation kinetics of tulane virus in cellculture medium and spinach. Journal of Food Science, 84(3), 557-563. https://doi.org/10.1111/1750-3841.14461.

Ainley, L. I., \& Hewitt, P. E. (2018). Haematology patients and the risk of transfusion transmitted infection. British Journal of Haematology, 180(4), 473-483. https://doi.org/10.1111/bjh.15030.
Allison, L., Salter, M., Mann, G., \& Howard, C. (1985). Thermal inactivation of pichinde virus. Journal of Virological Methods, 11(3), 259-264. https://doi.org/10.1016/0166-0934(85)90115-6.

Arthur, S., \& Gibson, K. (2015). Physicochemical stability profile of Tulane virus: A human norovirus surrogate. Journal of Applied Microbiology, 119(3), 868-875. https://doi.org/10.1111/ jam. 12878 .

Ausar, S. F., Foubert, T. R., Hudson, M. H., Vedvick, T. S., \& Middaugh, C. R. (2006). Conformational stability and disassembly of Norwalk virus-like particles: Effect of $\mathrm{pH}$ and temperature. Journal of Biological Chemistry, 281(28), 19478-19488. https ://doi.org/10.1074/jbc.M603313200.

Baccam, P., Beauchemin, C., Macken, C. A., Hayden, F. G., \& Perelson, A. S. (2006). Kinetics of influenza A virus infection in humans. Journal of Virology, 80(15), 7590-7599. https://doi. org/10.1128/JVI.01623-05.

Bachi, T., \& Howe, C. (1973). Morphogenesis and ultrastructure of respiratory syncytial virus. Journal of Virology, 12(5), 1173-1180.

Balayan, M., Andjaparidze, A., Savinskaya, S., Ketiladze, E., Braginsky, D., Savinov, A., et al. (1983). Evidence for a virus in non-A, non-B hepatitis transmitted via the fecal-oral route. Intervirology, 20(1), 23-31. https://doi.org/10.1159/000149370.

Barnes, R., Vogel, H., \& Gordon, I. (1969). Temperature of compensation: Significance for virus inactivation. Proceedings of the National Academy of Sciences USA, 62(1), 263-270. https://doi. org/10.1073/pnas.62.1.263.

Beauchemin, C. A., Kim, Y. I., Yu, Q., Ciaramella, G., \& DeVincenzo, J. P. (2019). Uncovering critical properties of the human respiratory syncytial virus by combining in vitro assays and in silico analyses. PLoS ONE, 14(4), e0214708. https://doi.org/10.1371/ journal.pone. 0214708 .

Belardo, G., Cenciarelli, O., La Frazia, S., Rossignol, J. F., \& Santoro, M. G. (2008). Use of murine norovirus as a surrogate to evaluate resistance of human norovirus to disinfectants. Applied and Environmental Microbiology, 74(10), 3315-3318. https://doi. org/10.1128/AEM.02148-07.

Beugeling, M., De Zee, J., Woerdenbag, H. J., Frijlink, H. W., Wilschut, J. C., \& Hinrichs, W. L. (2019). Respiratory syncytial virus subunit vaccines based on the viral envelope glycoproteins intended for pregnant women and the elderly. Expert Review of Vaccines, 18(9), 935-950. https://doi.org/10.1080/14760 584.2019.1657013.

Bodewes, R., \& Kuiken, T. (2018). Changing role of wild birds in the epidemiology of avian influenza A viruses. Advances in Virus Research, 100, 279-307. https://doi.org/10.1016/bs.aivir .2017.10.007.

Bouvier, N. M., \& Palese, P. (2008). The biology of influenza viruses. Vaccine, 26(4), D49-D53. https://doi.org/10.1016/j.vacci ne.2008.07.039.

Bowles, N., Richardson, P., Olsen, E., \& Archard, L. (1986). Detection of coxsackie B virus specific RNA sequences in myocardial biopsy samples from patients with myocarditis and dilated cardiomyopathy. Lancet, 1(8490), 1120-1124.

Bozkurt, H., D'Souza, D., \& Davidson, P. (2015). Thermal inactivation kinetics of hepatitis A virus in homogenized clam meat (mercenaria mercenaria). Journal of Applied Microbiology, 119(3), 834-844. https://doi.org/10.1111/jam.12892.

Burge, W., Cramer, W., \& Kawata, K. (1983). Effect of heat on virus inactivation by ammonia. Applied and Environmental Microbiology, 46(2), 446-451. https://doi.org/10.1128/ AEM.46.2.446-451.1983.

Cardozo, E. F., Andrade, A., Mellors, J. W., Kuritzkes, D. R., Perelson, A. S., \& Ribeiro, R. M. (2017). Treatment with integrase inhibitor suggests a new interpretation of HIV RNA decay curves that reveals a subset of cells with slow integration. PLoS Pathogens, 13(7), e1006478. https://doi.org/10.1371/journal.ppat.1006478. 
Cardozo, E. F., Ji, D., Lau, G., Schinazi, R. F., Feng, G., Ribeiro, R. M., et al. (2020). Disentangling the lifespans of hepatitis C virus-infected cells and intracellular vRNA replication-complexes during direct-acting anti-viral therapy. Journal of Viral Hepatitis, 27(3), 261-269. https://doi.org/10.1111/jvh.13229.

Carratala, A., Rusinol, M., Rodriguez-Manzano, J., GuerreroLatorre, L., Sommer, R., \& Girones, R. (2013). Environmental effectors on the inactivation of human adenoviruses in water. Food and Environmental Virology, 5(4), 203-214. https://doi. org/10.1007/s12560-013-9123-3.

Cartwright, T., Ritchie, A., \& Lauffer, M. (1956). The reaction of tobacco mosaic virus with formaldehyde. 3. Kinetics of the loss of infectivity. Virology, 2(5), 689-702. https://doi. org/10.1016/0042-6822(56)90048-4.

Casanova, L. M., Jeon, S., Rutala, W. A., Weber, D. J., \& Sobsey, M. D. (2010). Effects of air temperature and relative humidity on coronavirus survival on surfaces. Applied and Environmental Microbiology, 76(9), 2712-2717. https://doi.org/10.1128/ AEM.02291-09.

Chan, K., MalikPeiris, J., Lam, S., Poon, L., Yuen, K., \& Seto, W. (2011). The effects of temperature and relative humidity on the viability of the SARS coronavirus. Advances in Virology, 2011, 734690. https://doi.org/10.1155/2011/734690.

Chu, C., Hwang, S., Luo, J., Wang, Y., Lu, R., Lai, C., et al. (2001). Comparison of clinical, virologic and pathologic features in patients with acute hepatitis B and C. Journal of Gastroenterology and Hepatology, 16(2), 209-214. https://doi.org/10.104 6/j.1440-1746.2001.02422.x.

Ciesek, S., Friesland, M., Steinmann, J., Becker, B., Wedemeyer, H., Manns, M. P., et al. (2010). How stable is the hepatitis C virus (HCV)? Environmental stability of $\mathrm{HCV}$ and its susceptibility to chemical biocides. Journal of Infectious Diseases, 201(12), 1859-1866. https://doi.org/10.1086/652803.

Clenet, D. (2018). Accurate prediction of vaccine stability under real storage conditions and during temperature excursions. European Journal of Pharmaceutics and Biopharmaceutics, 125, 76-84. https://doi.org/10.1016/j.ejpb.2018.01.005.

Cook, N., Bertrand, I., Gantzer, C., Pinto, R., \& Bosch, A. (2018). Persistence of hepatitis A virus in fresh produce and production environments, and the effect of disinfection procedures: A review. Food and Environmental Virology, 10(3), 253-262. https://doi.org/10.1007/s12560-018-9349-1.

Corman, V., Lienau, J., \& Witzenrath, M. (2019). Coronaviruses as the cause of respiratory infections. Internist, 60(11), 11361145. https://doi.org/10.1007/s00108-019-00671-5.

Cristina, J., \& Costa-Mattioli, M. (2007). Genetic variability and molecular evolution of hepatitis A virus. Virus Research, 127(2), 151-157. https://doi.org/10.1016/j.virus res.2007.01.005.

Daher, D., Le Gourrierec, S., \& Perez-Lamela, C. (2017). Effect of high pressure processing on the microbial inactivation in fruit preparations and other vegetable based beverages. Agriculture Basel, 7(9), 72. https://doi.org/10.3390/agriculture7090072.

Daniel, C., \& Talbot, P. (1987). Physicochemical properties of murine hepatitis virus, strain A59. Archives of Virology, 96(3-4), 241248. https://doi.org/10.1007/BF01320963.

Davidson, I., Nagar, S., Haddas, R., Ben-Shabat, M., Golender, N., Lapin, E., et al. (2010). Avian influenza virus H9N2 survival at different temperatures and pHs. Avian Diseases, 54(1), 725-728. https://doi.org/10.1637/8736-032509-ResNote.1.

de Flora, S. (1978). Thermal inactivation of hepatitis B surface antigen. Journal of Immunology, 120(1), 40-45.

Dean, K., Wissler, A., Hernandez-Suarez, J. S., Nejadhashemi, A. P., \& Mitchell, J. (2020). Modeling the persistence of viruses in untreated groundwater. Science of the Total Environment, 717, 134599. https://doi.org/10.1016/j.scitotenv.2019.134599.
DeFord, D. M., Nosek, J. M., Castiglia, K. R., Hasik, E. F., Franke, M. E., Nick, B. C., et al. (2019). Evaluation of the role of respiratory syncytial virus surface glycoproteins $\mathrm{F}$ and $\mathrm{G}$ on viral stability and replication: Implications for future vaccine design. Journal of General Virology, 100(7), 1112-1122. https://doi.org/10.1099/ jgv.0.001287.

Dellanno, C., Vega, Q., \& Boesenberg, D. (2009). The antiviral action of common household disinfectants and antiseptics against murine hepatitis virus, a potential surrogate for SARS coronavirus. American Journal of Infection Control, 37(8), 649-652. https://doi.org/10.1016/j.ajic.2009.03.012.

Delrue, I., Verzele, D., Madder, A., \& Nauwynck, H. J. (2012). Inactivated virus vaccines from chemistry to prophylaxis: Merits, risks and challenges. Expert Review of Vaccines, 11(6), 695-719. https ://doi.org/10.1586/ERV.12.38.

Dimmock, N. (1967). Differences between thermal inactivation of picornaviruses at high and low temperatures. Virology, 31(2), 338-353. https://doi.org/10.1016/0042-6822(67)90179-1.

Dubuisson, J., \& Cosset, F. L. (2014). Virology and cell biology of the hepatitis C virus life cycle: An update. Journal of Hepatology, 61(1), S3-S13. https://doi.org/10.1016/j.jhep.2014.06.031.

Dumard, C. H., Barroso, S. P., Santos, A. C. V., Alves, N. S., Couceiro, J. N. S., Gomes, A. M., et al. (2017). Stability of different influenza subtypes: How can high hydrostatic pressure be a useful tool for vaccine development? Biophysical Chemistry, 231, 116-124. https://doi.org/10.1016/j.bpc.2017.04.002.

Echeverria, N., Moratorio, G., Cristina, J., \& Moreno, P. (2015). Hepatitis $\mathrm{C}$ virus genetic variability and evolution. World Journal of Gastroenterology, 7(6), 831-845. https://doi.org/10.4254/wjh. v7.i6.831.

Elena, S., Dopazo, J., Flores, R., Diener, T., \& Moya, A. (1991). Phylogeny of viroids, viroid-like satellite RNAs. and the viroid-like domain of hepatitis delta virus RNA. Proceedings of the National Academy of Sciences of the United States of America, 88(13), 5631-5634. https://doi.org/10.1073/pnas.88.13.5631.

Farkas, T. (2015). Rhesus enteric calicivirus surrogate model for human norovirus gastroenteritis. Journal of General Virology, 96(7), 1504-1514. https://doi.org/10.1099/jgv.0.000020.

Farkas, T., Sestak, K., Wei, C., \& Jiang, X. (2008). Characterization of a rhesus monkey calicivirus representing a new genus of Calicivitidae. Journal of Virology, 82(11), 5408-5416. https://doi. org/10.1128/JVI.00070-08.

Farnsworth, J. E., Goyal, S. M., Kim, S. W., Kuehn, T. H., Raynor, P. C., Ramakrishnan, M., et al. (2006). Genetic drift of influenza A(H3N2) viruses during two consecutive seasons in 20112013 in Corsica, France. Journal of Environmental Monitoring, 8(10), 1006-1013. https://doi.org/10.1039/b606132j.

Fischer, U., Weisz, W., Wieltschnig, C., Kirschner, A., \& Velimirov, B. (2004). Benthic and pelagic viral decay experiments: A modelbased analysis and its applicability. Applied and Environmental Microbiology, 70(11), 6706-6713. https://doi.org/10.1128/ AEM.70.11.6706-6713.2004.

Gibson, K. E., \& Schwab, K. J. (2011). Thermal inactivation of human norovirus surrogates. Food and Environmental Virology, 3(2), 74-77. https://doi.org/10.1007/s12560-011-9059-4.

Goh, S. G., Saeidi, N., Gu, X., Vergara, G. G. R., Liang, L., Fang, H., et al. (2019). Occurrence of microbial indicators, pathogenic bacteria and viruses in tropical surface waters subject to contrasting land use. Water Research, 150, 200-215. https://doi. org/10.1016/j.watres.2018.11.058.

González-Parra, G., \& Dobrovolny, H. M. (2015). Assessing uncertainty in A2 respiratory syncytial virus viral dynamics. Сотриtational and Mathematical Methods in Medicine, 2015, 567589. https://doi.org/10.1155/2015/567589.

González-Parra, G., Dobrovolny, H. M., Aranda, D. F., Chen-Charpentier, B., \& Roja, R. A. G. (2018). Quantifying rotavirus 
kinetics in the REH tumor cell line using in vitro data. Virus Research, 244, 53-63. https://doi.org/10.1016/j.virus res.2017.09.023.

Gosting, L., \& Gould, R. (1981). Thermal inactivation of infectious hematopoietic necrosis and infectious pancreatic necrosis viruses. Applied and Environmental Microbiology, 41(4), 1081-1082. https://doi.org/10.1128/AEM.41.4.1081-1082.1981.

Graiver, D. A., Topliff, C. L., Kelling, C. L., \& Bartelt-Hunt, S. L. (2009). Survival of the avian influenza virus (H6N2) after land disposal. Environmental Science and Technology, 43(11), 40634067. https://doi.org/10.1021/es900370x.

Green, I. (1970). Evidence for double-stranded nature of RNA of Colorado tick fever virus, an ungrouped arbovirus. Virology, 40(4), 1056. https://doi.org/10.1016/0042-6822(70)90152-2.

Grgacic, E., \& Schaller, H. (2000). A metastable form of the large envelope protein of duck hepatitis b virus: Low-ph release results in a transition to a hydrophobic, potentially fusogenic conformation. Journal of Virology, 74(11), 5116-5122. https://doi.org/10.1128/ JVI.74.11.5116-5122.2000.

Hambling, M. (1964). Survival of the respiratory syncytial virus during storage under various conditions. British Journal of Experimental Pathology, 45(6), 647-655.

Handel, A., Brown, J., Stallknecht, D., \& Rohani, P. (2013). A multiscale analysis of influenza A virus fitness trade-offs due to temperature-dependent virus persistence. PLoS Computational Biology, 9(3), e1002989. https://doi.org/10.1371/journal.pcbi.10029 89

Hansen, L., Van Renterghem, J., Daoussi, R., Vervaet, C., Remon, J. P., \& De Beer, T. (2016). Spectroscopic evaluation of a freeze-dried vaccine during an accelerated stability study. European Journal of Pharmaceutics and Biopharmaceutics, 104, 89-100. https:// doi.org/10.1016/j.ejpb.2016.04.010.

Hill, B. J., Underwood, B. O., Smale, C. J., \& Brown, F. (1975). Physico-chemical and serological characterization of five rhabdoviruses infecting fish. Journal of General Virology, 27(3), 369-378. https://doi.org/10.1099/0022-1317-27-3-369.

Hirneisen, K. A., \& Kniel, K. E. (2013). Comparing human norovirus surrogates: Murine norovirus and tulane virus. Journal of Food Protection, 76(1), 139-143. https://doi.org/10.4315/0362-028X. JFP-12-216.

Hogle, J. (2002). Poliovirus cell entry: Common structural themes in viral cell entry pathways. Annual Review of Microbiology, 56, 677-702. https://doi.org/10.1146/annurev.micro.56.01230 2.160757 .

Horman, W. S., Nguyen, T. H., Kedzierska, K., Bean, A. G., \& Layton, D. S. (2018). The drivers of pathology in zoonotic avian influenza: The interplay between host and pathogen. Frontiers in Immunology, 8, 1812. https://doi.org/10.3389/fimmu.2018.01812

Howard, C. (1995). The structure of hepatitis B envelope and molecular variants of hepatitis B virus. Journal of Viral Hepatitis, 2(4), 165-170. https://doi.org/10.1111/j.1365-2893.1995.tb00024.x.

Huangfu, C., Zhao, X., Lv, M., Jia, J., Zhu, F., Wang, R., et al. (2016). Inactivation of viruses during a new manufacturing process of alpha 2-macroglobulin from Cohn fraction IV by dry-heat treatment. Transfusion, 56(9), 2274-2277. https://doi.org/10.1111/ trf. 13714 .

Hui Chang, G., Oliver, E., Stanton, I., Wilson, M., Luo, B., Lin, L., et al. (2011). Genetic analysis of murine hepatitis virus nonstructural protein 16. Journal of General Virology, 92(1), 122127. https://doi.org/10.1099/vir.0.026781-0.

Incardona, N. (1974). Mechanism of adsorption and eclipse of bacteriophage-PHIX174.3. comparison of activation parameters for in vitro in vivo eclipse reactions with mutant and wild-type virus. Journal of Virology, 14(3), 469-478. https://doi.org/10.1128/ JVI.14.3.469-478.1974.
Johne, R., Trojnar, E., Filter, M., \& Hofmann, J. (2016). Thermal stability of hepatitis $\mathrm{E}$ virus as estimated by a cell culture method. Applied and Environmental Microbiology, 82(14), 4225-4231. https://doi.org/10.1128/AEM.00951-16.

Kaito, M., Ohba, H., Chiba, J., Kohara, M., Tanaka, H., Fujita, N., et al. (2006). The ultrastructural morphology of native hepatitis B virus. Medical Molecular Morphology, 39(3), 136-145. https ://doi.org/10.1007/s00795-006-0330-y.

Kampf, G., Todt, D., Pfaender, S., \& Steinmann, E. (2020). Persistence of coronaviruses on inanimate surfaces and their inactivation with biocidal agents. Journal of Hospital Infection, 104(3), 246-251. https://doi.org/10.1016/j.jhin.2020.01.022.

Karst, S., Wobus, C., Lay, M., Davidson, J., \& Virgin, H. (2003). STAT1-dependent innate immunity to a Norwalk-like virus. Science, 299(5612), 1575-1578. https://doi.org/10.1126/scien ce. 1077905 .

Keller, P. W., Morrison, O., Vassell, R., \& Weiss, C. D. (2018). HIV-1 gp41 residues modulate CD4-induced conformational changes in the envelope glycoprotein and evolution of a relaxed conformation of gp120. Journal of Virology, 92(16), e00583-18. https:// doi.org/10.1128/JVI.00583-18.

Kennedy, J. L., Turner, R. B., Braciale, T., Heymann, P. W., \& Borish, L. (2012). Pathogenesis of rhinovirus infection. Current Opinion in Virology, 2(3), 287-293. https://doi.org/10.1016/j.covir o.2012.03.008.

Ksiazek, T., Erdman, D., Goldsmith, C., Zaki, S., Peret, T., Emery, S., et al. (2003). A novel coronavirus associated with severe acute respiratory syndrome. New England Journal of Medicine, 348(20), 1953-1966. https://doi.org/10.1056/NEJMoa030781.

Kutter, J. S., Spronken, M. I., Fraaij, P. L., Fouchier, R. A., \& Herfst, S. (2018). Transmission routes of respiratory viruses among humans. Current Opinion in Virology, 28, 142-151. https://doi. org/10.1016/j.coviro.2018.01.001.

LaBarre, D., \& Lowy, R. (2001). Improvements in methods for calculating virus titer estimates from $T C I D_{50}$ and plaque assays. Journal of Virological Methods, 96(2), 107-126. https://doi. org/10.1016/S0166-0934(01)00316-0.

Laude, H. (1981). Thermal inactivation studies of a coronavirus, transmissible gastroenteritis virus. Journal of General Virology, 56, 235-240. https://doi.org/10.1099/0022-1317-56-2-235.

Lebarbenchon, C., Sreevatsan, S., Lefevre, T., Yang, M., Ramakrishnan, M. A., Brown, J. D., et al. (2012). Reassortant influenza A viruses in wild duck populations: Effects on viral shedding and persistence in water. Proceedings of the Royal Society $B$, 279(1744), 3967-3975. https://doi.org/10.1098/rspb.2012.1271.

Leblanc, D., Gagne, M. J., Poitras, E., \& Brassard, J. (2019). Persistence of murine norovirus, bovine rotavirus, and hepatitis $\mathrm{A}$ virus on stainless steel surfaces, in spring water, and on blueberries. Food Microbiology, 84, 103257. https://doi.org/10.1016/j. fm.2019.103257.

Lee, K., \& Gillespie, J. (1973). Thermal and pH stability of feline calicivirus. Infection and Immunity, 7(4), 678-679. https://doi. org/10.1128/IAI.7.4.678-679.1973.

Lee, W. J., Kim, Y. J., Kim, D. W., Lee, H. S., Lee, H. Y., \& Kim, K. (2012). Complete genome sequence of human respiratory syncytial virus genotype A with a 72-nucleotide duplication in the attachment protein G gene. Journal of Virology, 86(24), 13810 13811. https://doi.org/10.1128/JVI.02571-12.

Li, D., De Keuckelaere, A., \& Uyttendaele, M. (2015). Fate of foodborne viruses in the farm to fork chain of fresh produce. Comprehensive Reviews in Food Science and Food Safety, 14(6), 755-770. https://doi.org/10.1111/1541-4337.12163.

Liang, S., Lian, W., Leu, F., Lee, P., Chao, A., Hong, C., et al. (1995). Epizootic of low-virulence hepatotropic murine hepatitis virus in a nude mice breeding colony in Taiwan. Laboratory Animal Science, 45(5), 519-522. 
Lo, S., Gilbert, J., \& Hetrick, F. (1976). Stability of human enteroviruses in estuarine and marine waters. Applied and Environmental Microbiology, 32(2), 245-249. https://doi.org/10.1128/ AEM.32.2.245-249.1976.

Madani, T. A., Abuelzein, E. T. M., Azhar, E. I., \& Al-Bar, H. M. (2014). Thermal inactivation of Alkhumra hemorrhagic fever virus. Archives of Virology, 159(10), 2687-2691. https://doi. org/10.1007/s00705-014-2134-z.

Madani, T. A., Abuelzein, E. T. M., Azhar, E. I., Kao, M., Al-Bar, H. M., Abu-Araki, H., et al. (2012). Superiority of the buffy coat over serum or plasma for the detection of Alkhumra virus RNA using real time RT-PCR. Archives of Virology, 157(5), 819-823. https://doi.org/10.1007/s00705-012-1237-7.

Madani, T. A., Abuelzein, E. T. M., Jalalah, S. M., Abu-Araki, H., Azhar, E. I., Hassan, A. M., et al. (2017). Electron microscopy of Alkhumra hemorrhagic fever virus. Vector Borne Zoo Diseases, 17(3), 195-199. https://doi.org/10.1089/vbz.2016.2064.

Manuel, C. S., Moore, M. D., \& Jaykus, L. A. (2018). Predicting human norovirus infectivity: Recent advances and continued challenges. Food Microbiology, 76, 337-345. https://doi. org/10.1016/j.fm.2018.06.015.

Martins, A., Bersano, J., Ogata, R., Amante, G., Nastari, B., \& Catroxo, M. (2013). Diagnosis to detect porcine transmissible gastroenteritis virus (TGEV) by optical and transmission electron microscopy techniques. International Journal of Morphology, 31(2), 706-715.

McDougal, J., Martin, L., Cort, S., Mozen, M., Heldebrant, C., \& Evatt, B. (1985). Thermal inactivation of the acquired immunodeficiency syndrome virus, human T-lymphotropic virus-III/ lymphadenopathy-associated virus, with special reference to antihemophilic-factor. Journal of Clinical Investigation, 76(2), 875-877. https://doi.org/10.1172/JCI112045.

McKnight, K. L., Xie, L., Gonzalez-Lopez, O., Rivera-Serrano, E. E., Chen, X., \& Lemon, S. M. (2017). Protein composition of the hepatitis A virus quasi-envelope. Proceedings of the National Academy of Sciences of the United States of America, 114(25), 6587-6592. https://doi.org/10.1073/pnas.1619519114

McNaughton, A. L., D’Arienzo, V., Ansari, M. A., Lumley, S. F., Littlejohn, M., Revill, P., et al. (2019). Insights from deep sequencing of the HBV genome-unique, tiny, and misunderstood. Gastroentorology, 156(2), 384-399. https://doi.org/10.1053/j.gastr o.2018.07.058.

Meng, Z., Birch, C., Heath, R., \& Gust, I. (1987). Physicochemical stability and inactivation of human and simian rotaviruses. Applied and Environmental Microbiology, 53(4), 727-730. https://doi. org/10.1128/AEM.53.4.727-730.1987.

Miranda, R. C., \& Schaffner, D. W. (2019). Virus risk in the food supply chain. Current Opinion in Food Science, 30, 43-48. https:// doi.org/10.1016/j.cofs.2018.12.002.

Moore, M. D., Bobay, B. G., Mertens, B., \& Jaykus, L. A. (2016). Human norovirus aptamer exhibits high degree of target conformation-dependent binding similar to that of receptors and discriminates particle functionality. Msphere, 1(6), e00298-16. https://doi.org/10.1128/mSphere.00298-16.

Moss, L., \& Gravell, M. (1969). Ultrastructure and sequential development of infectious pancreatic necrosis virus. Journal of Virology, 3(1), 52-58. https://doi.org/10.1128/JVI.3.1.52-58.1969.

Nims, R. W., \& Zhou, S. S. (2016). Intra-family differences in efficacy of inactivation of small, non-enveloped viruses. Biologicals, 44(5), 456-462. https://doi.org/10.1016/j.biological s.2016.05.005.

Nyangao, J., Kingori, P., \& Okoth, F. A. (2006). Detection and identification of echovirus 7 from a child with gastro-enteritis. East African Medical Journal, 83(12), 666-669. https://doi.org/10.1137/ S003613990343882X.
Oshiro, L., \& Emmons, R. (1968). Electron microscopic observations of Colorado tick fever virus in BHK 21 and KB cells. Journal of General Virology, 3(2), 275. https://doi. org/10.1099/0022-1317-3-2-279.

Paek, M., Lee, Y., Yoon, H., Kang, H., Kim, M., Choi, J., et al. (2010). Survival rate of $\mathrm{H} 5 \mathrm{~N} 1$ highly pathogenic avian influenza viruses at different temperatures. Poultry Science, 89(8), 1647-1650. https://doi.org/10.3382/ps.2010-00800.

Palmer, J., Dobrovolny, H. M., \& Beauchemin, C. A. (2017). The in vivo efficacy of neuraminidase inhibitors cannot be determined from the decay rates of influenza viral titers observed in treated patients. Scientific Reports, 7, 40210. https://doi.org/10.1038/ srep40210.

Patton, J. (1986). Synthesis of simian rotavirus SA11 double-strandedRNA in a cell-free system. Virus Research, 6(3), 217-233. https ://doi.org/10.1016/0168-1702(86)90071-7.

Paules, C. I., Marston, H. D., \& Fauci, A. S. (2020). Coronavirus infections-more than just the common cold. JAMA, 123(8), 707-708.

Perelson, A. S., Neumann, A., Markowitz, M., Leonard, J., \& Ho, D. (1996). HIV-1 dynamics in vivo: Virion clearance rate, infected cell life-span, and viral generation time. Science, 271(5255), $1582-1586$.

Pinon, A., \& Vialette, M. (2018). Survival of viruses in water. Intervirology, 61(5), 214-222. https://doi.org/10.1159/000484899.

Poiesz, B., Ruscetti, F., Gazdar, A., Bunn, P., Minna, J., \& Gallo, R. (1980). Detection and isolation of type-C retrovirus particles from fresh and cultured lymphocytes of a patient with cutaneous T-cell lymphoma. Proceedings of the National Academy of Sciences of the United States of America, 77(12), 7415-7419. https://doi.org/10.1073/pnas.77.12.7415.

Poryvaev, V. (1995). Thermodynamic analysis of oxidative inactivation of influenza virus and lipid peroxidation in virus envelopes. Russian Program in Virology, 40(6), 273-276. https://doi. org/10.1159/000319033.

Prasad, B., Wang, G., Clerx, J., \& Chiu, W. (1988). 3-dimensional structure of rotavirus. Journal of Molecular Biology, 109(2), 269-275. https://doi.org/10.1016/0022-2836(88)90313-0.

Predmore, A., Sanglay, G., Li, J., \& Lee, K. (2015). Control of human norovirus surrogates in fresh foods by gaseous ozone and a proposed mechanism of inactivation. Food Microbiology, 50, 118-125. https://doi.org/10.1016/j.fm.2015.04.004.

Rabinowitz, P., Perdue, M., \& Mumford, E. (2010). Contact variables for exposure to avian influenza $\mathrm{H} 5 \mathrm{~N} 1$ virus at the human-animal interface. Zoonoses and Public Health, 57(4), 227-238. https:// doi.org/10.1111/j.1863-2378.2008.01223.x.

Randazzo, I. F. W., Gomez-Mascaraque, L., Aznar, R., Lopez-Rubio, A., \& Sanchez, G. (2017). Effect of of (-)-epigallocatechin gallate at different $\mathrm{pH}$ conditions on enteric viruses. Food Science and Technology, 81, 250-257. https://doi.org/10.1016/j. lwt.2017.03.050.

Rasche, A., Sander, A. L., Corman, V. M., \& Drexler, J. F. (2019). Evolutionary biology of human hepatitis viruses. Journal of Hepatology, 70(3), 501-520. https://doi.org/10.1016/j.jhep.2018.11.010.

Rasschaert, D., Gelfi, J., \& Laude, H. (1987). Enteric coronavirus TGEV: Partial sequence of the genomic RNA, its organization and expression. Biochimie, 69(6-7), 591-600. https://doi. org/10.1016/0300-9084(87)90178-7.

Rechsteiner, J. (1968). Thermal inactivation of respiratory syncytial virus in water and hypertonic solutions. Journal of General Virology, 5(3), 397-403.

Rossmann, M., Arnold, E., Erikson, J., Frankenberger, E., Griffith, J., Hecht, H., et al. (1985). Structure of a human common cold virus and functional relationship to other picornaviruses. Nature, 317(6033), 145-153. https://doi.org/10.1038/317145a0.

Roy, A., Parker, J., Parrish, C., \& Whittaker, G. (2000). Early stages of influenza virus entry into Mv-1 lung cells: Involvement of 
dynamin. Virology, 267(1), 17-28. https://doi.org/10.1006/ viro.1999.0109.

Sano, M., Okamoto, N., Fukuda, H., Saneyoshi, M., \& Sano, T. (1992). Virulence of infectious pancreatic necrosis virus is associated with the larger RNA segment (RNA segment A). Journal of Fish Diseases, 15(4), 283-293. https://doi. org/10.1111/j.1365-2761.1992.tb00666.x.

Sarda, C., Palma, P., \& Rello, J. (2019). Severe influenza: Overview in critically ill patients. Current Opinion in Critical Care, 25(5), 449-457. https://doi.org/10.1097/MCC.0000000000000638.

Schaffer, F., \& Schwerdt, C. (1959). Purification and properties of poliovirus. Advances in Virus Research, 6, 159-204. https://doi. org/10.1016/S0065-3527(08)60491-1.

Seal, L., \& Jamison, R. (1984). Evidence for secondary structure within the virion RNA of echovirus-22. Journal of Virology, 50(2), 641-644. https://doi.org/10.1128/JVI.50.2.641-644.1984.

Sell, J., \& Dolan, B. (2018). Common gastrointestinal infections. Primary Care, 45(3), 519. https://doi.org/10.1016/j. pop.2018.05.008.

Seo, K., Lee, J. E., Lim, M. Y., \& Ko, G. (2012). Effect of temperature, $\mathrm{pH}$, and $\mathrm{NaCl}$ on the inactivation kinetics of murine norovirus. Journal of Food Protection, 75(3), 533-540. https://doi. org/10.4315/0362-028X.JFP-11-199.

Siegl, G., \& Frosner, G. (1987). Characterization and classification of virus particles associated with hepatitis A. 1. Size, density, and sedimentation. Journal of Virology, 26(1), 40-47. https://doi. org/10.1128/JVI.26.1.40-47.1978.

Silnikov, V., \& Plotnikov, E. (2018). In vitro effects of a novel silverbased complex on influenza virus. Journal of Pharmacology and Pharmacotherapeutics, 9(4), 186-190. https://doi.org/10.4103/ jpp.JPP_50_18.

Silva, J. L., Barroso, S. P., Mendes, Y. S., Dumard, C. H., Santos, P. S., Gomes, A. M., et al. (2015). Pressure-inactivated virus: A promising alternative for vaccine production. Antimicrobial Agents and Chemotherapy, 72, 301-318. https://doi. org/10.1007/978-94-017-9918-8_15.

Snowden, J., Cliver, D., \& Converse, J. (1989). Inactivation of poliovirus-1, as a function of temperature, in mixed human and dairy animal wastes. Waste Management and Research, 7(2), 135-142. https://doi.org/10.1371/journal.pcbi.1001081.

Snyder, A. J., Wang, J. C. Y., \& Danthi, P. (2019). Components of the reovirus capsid differentially contribute to stability. Journal of Virology, 93(2), e01894. https://doi.org/10.1128/JVI.01894-18.

Sohal, R., \& Burch, G. (1969). Electron microscopy study of the endocardium in coxsackie virus B4 infected mice. American Journal of Pathology, 55(1), 133-145.

Song, H., Li, J., Shi, S., Yan, L., Zhuang, H., \& Li, K. (2010). Thermal stability and inactivation of hepatitis $\mathrm{C}$ virus grown in cell culture. Virology Journal, 7, 40. https://doi. org/10.1186/1743-422X-7-40.

Stein, R. T., Bont, L. J., Zar, H., Polack, F. P., Park, C., Claxton, A., et al. (2017). Respiratory syncytial virus hospitalization and mortality: Systematic review and meta-analysis. Pediatric Pulmonology, 52(4), 556-569. https://doi.org/10.1002/ppul.23570.

Su, C., Wu, J., Huang, Y., Huo, T., Huang, Y., Lin, C., et al. (2002). Comparison of clinical manifestations and epidemiology between acute hepatitis A and acute hepatitis E in Taiwan. Journal of Gastroenterology and Hepatology, 17(11), 1187-1191. https://doi. org/10.1046/j.1440-1746.2002.02858.x.

Tamrakar, S., Henley, J., Gurian, P., Gerba, C., Mitchell, J., Enger, K., et al. (2017). Persistence analysis of poliovirus on three different types of fomites. Journal of Applied Microbiology, 122(2), 522-530. https://doi.org/10.1111/jam.13299.
Than, T. T., Jo, E., Todt, D., Nguyen, P. H., Steinmann, J., Steinmann, E., et al. (2019). High environmental stability of hepatitis B virus and inactivation requirements for chemical biocides. Journal of Infectious Diseases, 219(7), 903-907. https://doi.org/10.1093/ infdis/jiy620.

Tian, P., Yang, D., Quigley, C., Chou, M., \& Jiang, X. (2013). Inactivation of the Tulane virus, a novel surrogate for the human norovirus. Journal of Food Protection, 76(4), 712-718. https:// doi.org/10.4315/0362-028X.JFP-12-361.

Totaro Garcia, L. A., \& Monte Barardi, C. R. (2019). Performance of a storage tank coupled with UV light on enteric virus inactivation in drinking water. Water Science and Technology, 19(4), 1103-1109. https://doi.org/10.2166/ws.2018.161.

Trent, D., \& Scott, L. (1966). Colorado tick fever virus in cell culture. 2. Physical and chemical properties. Journal of Bacteriology, 91(3), 1282-1288.

Vekemans, J., Moorthy, V., Giersing, B., Friede, M., Hombach, J., Arora, N., et al. (2019). Respiratory syncytial virus vaccine research and development: World Health Organization technological roadmap and preferred product characteristics. Vaccine, 37(50), 7394-7395. https://doi.org/10.1016/j.vacci ne.2017.09.092.

Vyazovkin, S. (2016). A time to search: Finding the meaning of variable activation energy. Physical Chemistry Chemical Physics: PCCP $, 18(28), 18643-18656$. https://doi.org/10.1039/c6cp0 2491b.

Walsh, E. E., Peterson, D. R., \& Falsey, A. R. (2013). Viral shedding and immune responses to respiratory syncytial virus infection in older adults. Journal of Infectious Diseases, 207, 1424-1432. https://doi.org/10.1093/infdis/jit038.

Ward, R., Knowlton, D., \& Winston, P. (1986). Mechanism of inactivation of enteric viruses in fresh water. Applied and Environmental Microbiology, 52(3), 450-459. https://doi.org/10.1128/ AEM.52.3.450-459.1986.

Whitehurst, C. B., Soderblom, E. J., West, M. L., Hernandez, R., Goshe, M. B., \& Brown, D. T. (2007). Location and role of free cysteinyl residues in the sindbis virus E1 and E2 glycoproteins. Journal of Virology, 82(12), 6231-6240. https://doi.org/10.1128/ JVI.02859-06.

Wigginton, K. R., Menin, L., Montoya, J. P., \& Kohn, T. (2010). Oxidation of virus proteins during UV254 and singlet oxygen mediated inactivation. Environmental Science and Technology, 44(14), 5437-5443. https://doi.org/10.1021/es100435a.

Yeargin, T., Buckley, D., Fraser, A., \& Jiang, X. (2016). The survival and inactivation of enteric viruses on soft surfaces: A systematic review of the literature. American Journal of Infection Control, 44(11), 1365-1373. https://doi.org/10.1128/ AAC.49.10.4075-4084.2005.

Yue, C., Teitz, S., Miyabashi, T., Boller, K., Lewis-Ximenez, L. L., Baylis, S. A., et al. (2019). Inactivation and removal of chikungunya virus and mayaro virus from plasma-derived medicinal products. Viruses, 11(3), 234. https://doi.org/10.3390/v11030234.

Zhou, L., Yu, Q., \& Luo, M. (1994). Characterization of 2 density populations of feline calicivirus particles. Virology, 205(2), 530-533. https://doi.org/10.1006/viro.1994.1674.

Publisher's Note Springer Nature remains neutral with regard to jurisdictional claims in published maps and institutional affiliations. 